\title{
SOBRE A TAREFA DA DESCONSTRUÇÃO E A QUESTÃO DO FUNDAMENTO NEGATIVADO: POR UMA ÉTICA DA FINITUDE
}

Thalles Azevedo de Araújo Universidade de Coimbra - F.C.T.

\section{A dimensão de uma ética da finitude na ontologia fundamental}

Nascida na tradição fenomenológica, Sein und Zeit, de 1927, coloca a questão do sentido do ser e se esforça em desconstruir a metafísica tradicional do puramente subsistente com seu conceito de ser como presença e de tempo como tempo presente. Heidegger, em sua ruptura com a subjetividade do pensamento ocidental, desconstrói também o princípio das éticas infinitistas ${ }^{1}$, segundo o qual todo agir humano obedece a máximas universais e a todo dever absoluto e agir causal. Ainda podemos dizer que não somente a ética, mas, também, as ontologias se organizaram em torno do infinitismo. O infinitismo, por sua vez, se pautou no princípio do fundamento. Para esse princípio, nada é ou existe sem fundamento, o assim chamado princípio da razão suficiente ou princípio da causalidade. Pelo princípio da causalidade, entenda-se que todo o ente tem a razão ou o fundamento de ser; aqui o ente se refere a tudo o que pode

1 O infinitismo das éticas tradicionais, assim como o das ontologias, encontra apoio no princípio de fundamento. Nas éticas, o infinitismo, se manifesta por meio de máximas e regras que servem de fundamento para o raciocínio prático e o agir, e vigoram incondicionalmente. A esse respeito, podemos apontar quatro tipos de éticas infinitistas: a) as que têm o agir como dever (éticas infinitistas); b) as que buscam paliativos para o desprazer e a maxjmização do prazer (éticas da satisfação); c) as que prometem a imortalidade (éticas da salvação); d) as que pretendem a socialização, integração e pacificação (éticas da reconciliação). Todas elas trabalhariam para uma eliminação dos problemas da finitude. A desconstrução da metafisica empreendida por Heidegger implicaria também uma desconstrução dessas éticas, abrindo a possibilidade de uma ética da finitude. 
ser dito. O existente supremo é dito ter a razão ou a causa em si, portanto, ele é a causa de si. Sobre esse aspecto, Loparic ressalta que essas éticas pretendem a "eliminação da finitude caracterizada pelo desprazer, a transitoriedade e os conflitos."2

Aquém do princípio de fundamento da razão suficiente das éticas tradicionais que nos diz: nihil est sine ratione (nada é ou existe sem fundamento), proporemos mostrar que a ética heideggeriana vislumbrada a partir da ontologia fundamental, é uma ética de ser-no-mundo, do morar no mundo-projeto, longe dos poderes nadificantes da razão/consciência, mas perto de sua possibilidade mais própria: a de ser-para-a-morte, revelada na consciência do ser-em-débito e ouvida no silêncio disposto para a angústia. $\mathrm{O}$ todo que a morte prenuncia, contrai, num único momento certo e indeterminado, o fundamento negativado sobre o qual projeta aquilo em que podemos tornar-nos, ou seja, a conquista de si mesmo, pela qual supera a envolvência do cotidiano é produto de um exercitamento para o morrer. Antecipando a morte, e compreendendo enquanto verdade genuína e originária, o Dasein contraria a esquivança protetora e tranquilizante da queda, e tem implicações de ordem ética. ${ }^{3}$

Esta possível leitura ética da ontologia fundamental não pergunta mais: que devo fazer para ser digno de ser feliz? E sim: como deixar acontecer estando-aí no mundo, o que tem-que-ser? ${ }^{4}$ Aqui, é importante aclarar que ter-que-ser é a tradução existencial ontológica do conceito metafísico do ter-de-ser. Se para a tradição, ter-de-ser significa ter o dever de seguir aquilo que é prescrito pela lei moral, o ter-que-ser heideggeriano se refere, de modo anterior a qualquer prescrição de uma lei moral, a uma urgência (Not) que incide sobre nós como o peso de um enigma sem razão suficiente. Ele nos é imposto pelo nosso ser, ele mesmo. Assim, Loparic observa que Heidegger não deixou dúvidas: o agir moral, regulamentado pela ética tradicional, é um agir causal, ou seja, do mesmo tipo do agir técnico. Isto quer dizer que, para Heidegger, desde o imperativo categórico de Kant, "o tipo das leis morais é o mesmo das leis da natureza; que a razão instrumental e a razão prática são no essencial a mesma razão definida pela obediência ao princípio de fundamento." 5 De antemão, deve-se assinalar que, se em Sein und Zeit há elementos originários de uma possível ética, eles estão longe do domínio objetivante da razão suficiente. Que não haja uma ética ordenada ao modo metafísico, e que Heidegger nem sequer demonstrou

2 LOPARIC, Z. Ética e finitude. 2. ed. São Paulo: Escuta, 2004. p. 59.

3 NUNES, B. Passagem para o poético: filosofia e poesia em Heidegger. São Paulo: Editora Ática, 1992. p. 54.

${ }^{4}$ Cf. LOPARIC, Z. Ética e finitude. Op. cit., p. 59.

5 Ibid., p. 56. 
interesse em escrever tal ética, isso sabemos. Contudo, acreditamos que Sein und Zeit deixa entrever a possibilidade de uma ética originária.

Se consideramos certo que a via sugerida por Heidegger para superar a metafísica se deu através da necessidade de recolocar a questão sobre o sentido do ser, a partir do horizonte da temporalidade finita do Dasein, isto é, se consideramos certo que Heidegger nos restabeleceu de um pensamento esquecido da finitude do ser, também é certo que, para superar as teorias éticas nascidas no interior desta metafísica, temos que trazer para dentro da própria ética a questão da finitude. Ao levar adiante o seu projeto de desconstrução da história da metafísica ocidental, Heidegger, ao mesmo tempo, possibilitou a desconstrução das éticas tradicionais, razão pela qual, como afirma Loparic, a alternativa heideggeriana para a metafísica como teoria do ser-presentidade conterá, também e necessariamente, uma alternativa finitista para as éticas tradicionais. Desmontar a metafísica como teoria das faces da presença do ser (faces visíveis para o olhar da razão), como teoria esquecida do problema do Dasein como tal, é o mesmo que desconstruir as éticas da realização de ações de satisfação, salvação ou reconciliação numa totalidade cósmica ou social. ${ }^{6}$

"Quando escreverá o senhor uma Ética?" Foi o que perguntaram a Heidegger logo que publicou Sein und Zeit. Em Brief über den »Humanismus«, o próprio Heidegger assinala que: “A aspiração por uma Ética urge com tanto mais pressa por uma realização, quanto mais a perplexidade manifesta do homem e, não menos, a oculta, se exacerba para além de toda medida." $\mathrm{O}$ apelo a uma ética, assim, provém da completa desorientação do homem atual, revelando-se como algo que indica o caminho mais seguro ou mais adequado a seguir. A ética tradicional, erguida sob as pilastras da infinitude, vem tentar trazer respostas aos diversos problemas do homem, oferecendo-lhe uma orientação segura sobre o dever pensar e o dever agir. Com isso, é mais do que esperado que Heidegger se esquive de uma tal ética ou de qualquer esforço de conduzir o homem a esquemas explicativos do controle da subjetividade.

Quando lemos a pergunta: quando escreverá o senhor uma Ética?, somos levados a indicar que a única resposta pronta que Heidegger poderia ter dado ao seu interlocutor era que a Ética exigida já estava escrita ao longo do desenvolvimento da questão do ser. ${ }^{9}$ Mais importante do que qualquer cânone de regras ou modelo absoluto de agir moral é o homem estar aberto à

${ }^{6}$ Cf. Ibid., p. 53.

7 HEIDEGGER, M. "Brief über den »Humanismus«". In: Wegmarken, GA 9. Frankfurt am Main: Vittorio Klostermann, 1976. p. 353.

8 Ibid., p. 353.

9 Cf. NUNES, B. Crivo de papel. 2. ed. São Paulo: Ática, 1998. p. 194. 
compreensão da verdade do ser, isto é, o "[...] pensar que pensa a verdade do ser como o elemento primordial do homem enquanto alguém que ec-siste já é em si uma ética originária." ${ }^{10} \mathrm{O}$ pensamento da verdade do ser é o pensamento conforme a essência do ec-sistente, é o pensamento do aberto como lugar do aparecimento epocal do que se manifesta. Trata-se, pois, de um pensamento que destitui o humano do seu caráter metafísico moderno enquanto senhor do ser, privando-o da posição privilegiada que ele aí ocupa em relação a todos os entes, para então poder considerar, pela primeira vez, sua essência: o ec-sistir como projeto lançado pelo ser na clareira do ser, da qual ele deve cuidar como um pastor.

É assim que, mais urgente e anterior a qualquer construção ou reconstrução de uma ética, é pensar a presença da história como o destino do pensamento do ser. E uma ética digna deste nome, só seria possível após a consolidação de um pensamento não representacional. Isso porque, no âmbito do pensamento representacional, o campo da ação deve se mostrar afeito aos critérios de rigor da teoria, ou do controle da subjetividade, do cálculo, em suma, da representação. A tarefa de Heidegger aponta para uma exigência: a de que é preciso fazer uma experiência do pensar para além da representação. Assim, eis a razão de o autor de Sein und Zeit não ter empreendido um estudo específico sobre ética: porque tendo suas raízes no alicerce da metafísica, ela desobriga o pensar de considerar aquilo que principalmente deve ser pensado. Não obstante, é bem plausível encontrarmos uma dimensão ética no horizonte teórico heideggeriano, porém radicalmente distinta da ética tradicional. $\mathrm{O}$ agir, numa ética finitista, não significa mais produzir efeitos; não há prazeres a buscar, bens a realizar, normas a cumprir, mas, de modo contrário, trata-se de um agir por ter-que-agir, desapegado de todos os fundamentos afetivos e racionais, às claras quanto a sua instransponível transiência.

Da perspectiva de uma consideração originária da ética, jamais se tratará de impor valores ao outro, nem de pré-determinar as regras e procedimentos teóricos e práticos a partir dos quais se poderia garantir a vida boa em comum; antes, e principalmente, trata-se de pensar e agir no sentido de uma ética do deixar-ser, capaz de deixar transparecer no outro a liberdade para decidir pelo seu poder-ser mais próprio. Segundo Duarte, esta ética também pode ser chamada de uma ética da precariedade, justamente pelo fato de estar vinculada à inexistência de princípios ou fundamentos metafísicos que possam operar como critérios transcendentais de validação da qualidade ética da conduta humana. Uma ética da precariedade seria o efeito colateral necessário do reconhecimento da finitude do ser e do próprio Dasein, cuja existência, sendo

${ }^{10}$ HEIDEGGER, M. "Brief über den »Humanismus«". In: Wegmarken, GA 9. Op. cit., p. 356. 
lançada no mundo em que se projeta, é ontologicamente desprovida de fundamentos últimos, é sem-porquê, tornando vão qualquer empreendimento teórico que tenciona fundamentar moralmente ou cognitivamente os seus projetos mundanos. ${ }^{11}$

No artigo La Question de l'Éthique après Heidegger, Alain Renault e Luc Ferry afirmam que nos textos de Heidegger, paradoxalmente, a dimensão ética não está de modo algum ausente. Eles sugerem que há uma espécie de denegaçã $o^{12}$, na medida em que o pensador alemão, posicionando-se contra $a$ ética nos moldes da metafísica, no sentido de uma recusa de escrever ele mesmo um estudo sobre ética, faz uso de termos imbuídos de conotações éticas, tais como: decadência, culpa, consciência, autenticidade, inautenticidade:

[...] o objetivo desta prática da denegação é, consequentemente, muito claro: expulsar todas as conotações moralizantes incompatíveis com a visão de um empreendimento que se esforça por pensar o fim do homem como sujeito. Todo o problema é, no entanto, o de compreender por que estas conotações são introduzidas: por que dar ao propósito uma coloração ética tão marcada? ${ }^{13}$

No artigo citado acima, Renault e Ferry vão na direção de indicar que esses traços marcantes de uma ética em Heidegger são relacionados a um problema específico: o problema de dizer o ser que não seja pelo viés de uma linguagem metafísica. Ora, Heidegger emprega os mesmos nomes utilizados na metafísica, mas os destitui dos sentidos propriamente metafísicos, passando a ser entendidos analogicamente ou metaforicamente. É disso que surge o uso tão frequente de aspas, itálicos, maiúsculas, buscando de todas as maneiras, demarcar sem poder verdadeiramente dizer a diferença entre isto que significam os termos empregados e o que querem significar. Diante desse contexto, importa-nos perguntar: que ética podemos vislumbrar na ontologia fundamental? Em Sein und Zeit, com um tom de interrogação, Heidegger escreve: "Mas será que esta interpretação ontológica da existência do Dasein, aqui desenvolvida, não tem por base uma determinada concepção da existência própria, isto é, um ideal de fato do Dasein? Tal é o caso." ${ }^{14}$ A analítica existencial é uma análise ontológica, mas, ao mesmo tempo, também é uma análise ôntica da existência do Dasein, afinal, ele é compreendido ontologicamente no modo de ser da

${ }^{11}$ Cf. DUARTE, A. Por uma ética da precariedade: sobre o traço ético de Ser e Tempo. In: Revista Natureza Humana, São Paulo, ano 1, v. 2., n. 1, 2000 . p. 74.

${ }^{12}$ Cf. FERRY, L; RENAULT, A. La Question de l'éthique après Heidegger. In: Système et Critique. Essais sur la critique de la raison dans la philosophie contemporaine. Bruxelles: Ousia, 1992. p. 86.

${ }^{13}$ Ibid., p. 86-87.

${ }^{14}$ HEIDEGGER, M. Sein und Zeit. Tübingen: Max Niemeyer Verlag, 1967. p. 310. 
cotidianidade, do impessoal (das Man).

Na medida em que é análise do Dasein, a ontologia fundamental pode indicar o lugar no qual o ser e o ser humano (Dasein) e os seres humanos entre si (Mitsein) se relacionam. Pode-se pensar, com Hodge, que, enquanto o Dasein é o lugar onde o ser se revela, o lugar onde se revela o Dasein é o ser humano, individual e coletivo. A ontologia fundamental é, portanto, ontológica, preocupada com as condições gerais da possibilidade da existência, e é ôntica, preocupada com a efetiva existência de seres humanos. ${ }^{15}$ Por conseguinte, a possibilidade de uma interpretação ética de Sein und Zeit se deixa entrever a partir de afirmações como as de que "como ser-no-mundo articulado em compreensões com os outros, o Dasein 'obedece' na escuta à coexistência e a si próprio como pertencente a essa obediência" 16 e de que "o ser-com se forma [ausbildet] no escutar recíproco de um e outro." ${ }^{17}$ Portanto, é na escuta atenta e silenciosa ao outro do si-impessoal que todos trazemos junto a nós mesmos, bem como é na escuta apropriada ao outro da coexistência cotidiana, que o Dasein dá a compreender a possibilidade de uma forma de solicitude que não se substitui a outrem como um passo em frente no seu potencial, sem lhe retirar o seu cuidado, mas devolvendo-lhe esse cuidado pela primeira vez e de forma genuína como se sua fosse. Esta forma de solicitude ajuda o outro a tornar-se perspicaz no seu cuidado e a tornar-se livre para o exercer. Só através de uma relação consigo mesmo é possível exprimir o cuidado genuíno por outrem, até mesmo reconhecer como suas as preocupações do outro. ${ }^{18}$

Entretanto, é importante que se faça a distinção entre a investigação ôntico-empírica e a investigação ontológico-transcendental. O que interessa para Heidegger não são os conteúdos vivenciais da existência, os conteúdos quididativos, tal como Husserl o fez, mas sim a descrição fenomenológica do como do existir humano. De modo que o Dasein possa mostrar-se em si mesmo e por si mesmo, na cotidianidade "não se devem retirar estruturas ocasionais e acidentais, mas estruturas essenciais. Essenciais são as estruturas que se mantêm ontologicamente determinantes em todo modo de ser do Dasein em sua facticidade." ${ }^{19}$ Será esta a medida tomada em nosso trabalho ao buscar delinear a possibilidade de uma dimensão ética em Sein und Zeit. Será, portanto, uma ética originária, respaldada à luz da questão do ser. A ética heideggeriana apresenta um caráter original, pois trata-se de uma ética cuja

${ }^{15}$ Cf. HODGE, J. Heidegger e a ética. Trad. de Gonçalo C. Feio. Lisboa: Instituto Piaget, 1998. p. $47-48$.

${ }^{16}$ HEIDEGGER, M. Sein und Zeit. Op. cit., p. 163.

${ }^{17}$ Ibid., p. 163.

${ }^{18}$ Cf. HODGE, J. Heidegger e a ética. Op. cit., p. 303.

${ }^{19}$ HEIDEGGER, M. Sein und Zeit. Op. cit., p. 16-17. 
base é o reconhecimento da finitude do ser e do Dasein. Dessa forma analisada, justifica Nunes: a finitude 'possibilita, ao mesmo tempo, a 'destruição' dos sistemas morais (éticas infinitistas da salvação, do dever, do prazer e da utilidade) - paralelamente à da metafísica - e a libertação da Ética originária, já escrita desde Sein und Zeit."20

\section{A angústia como abertura originária ao poder-ser próprio}

Toda a concepção do Dasein, enquanto ser-no-mundo, assenta-se na sua compreensão. A sua compreensão de mundo e de si mesmo é, de início e no mais das vezes, uma compreensão mediana estabelecida pelo impessoal. O domínio do impessoal sustém-se na linguagem compartilhada que se atribui no falatório. No entanto, há uma possibilidade própria para a compreensão, sendo que o modo pelo qual ela se torna propriamente si mesma decorre de uma ruptura originada por uma tonalidade afetiva: a angústia. $\mathrm{O}$ fenômeno da angústia é o que se manifesta como possibilidade de abertura mais abrangente e mais originária. Trata-se da abertura privilegiada que remove do Dasein a possibilidade de se compreender a partir do seu poder-ser mais imediato e factual, isto é, da interpretação pública, na qual está imerso enquanto uma das possibilidades de ser-no-mundo das ocupações e ser-com os outros. O Dasein encontra-se, em seu poder-ser impróprio, perdido na publicidade do impessoal, dando ouvidos ao que todo-mundo diz, e isso o faz esquecer-se de se ouvir a si-próprio. O Dasein se acha de tal forma submergido entre as coisas, que se esquece a si mesmo. Tal acontecimento ocorre na cotidianidade, onde o Dasein anda preocupado com as coisas exteriores sem encontrar-se a si mesmo. É uma maneira de existir que Kierkegaard, por exemplo, define como muito cômoda e feliz, no entanto o eu (expressão kierkegaardiana) não é um verdadeiro $e u$ que tem consciência e domínio de seu próprio destino, senão que está levado pelas coisas transitórias do mundo. Em tal caso, afirma Kierkegaard, o eu não existe, nada o representa em si mesmo, senão que "em vez de um eu se torna um número, mais um ser humano, mais uma repetição de um eterno zero." ${ }^{21}$ Heidegger certamente tomou esta análise do filósofo dinarmaquês, chamando-a de existência imprópria, o impessoal (das Man). Este rumor típico da ambiguidade múltipla e variada do falatório é o modo de ser-como-todo-mundo, por isso, é a aderência ao eu-também que deve ser rompido na experiência fundamental da angústia.

${ }^{20}$ NUNES, B. Crivo de papel. Op. cit., p. 197.

${ }^{21}$ KIERKEGAARD, S. A. O desespero humano: doença até a morte. Trad. de Adolfo C. Monteiro. São Paulo: Abril Cultural, 1979. p. 30. 
Na conferência Was ist Metaphisik?, o intuito de Heidegger $\boldsymbol{e}$ passar do discurso ôntico, científico, ao ser do ente por meio do nada. $\mathrm{O}$ nada não pode ser pensado como um simples conceito do entendimento, mas, sim, como uma experiência, em que à compreensão articula-se uma disposição de humor. Na referida conferência, Heidegger aprofunda a relação entre a angústia e o nada. Logo nas primeiras linhas, aponta que a pergunta pela metafísica é uma pergunta pelo ente. Entretanto, na pergunta pelo ente a questão do nada aparece, embora esquecida, no início, pela ciência. Heidegger questiona se aquilo que a ciência não se preocupa em investigar, não tem um significado ontológico mais fundamental. A análise do nada começa por um aclaramento do sentido da angústia. A angústia nos traz à presença do nada, mesmo que raramente. Nessa circunstância, Heidegger pergunta: "acontece no Dasein semelhante disposição de humor na qual ele seja levado à presença do próprio nada?"22, sua resposta é de que "este acontecer é possível e também real - ainda que bastante raro - apenas por instantes, na disposição de humor fundamental da angústia." ${ }^{23}$ A angústia é, pois, um fenômeno fundamental, isto conduz o Dasein a romper uma familiaridade habitual que se dá no seu modo de ser nivelado pelo impessoal e dispersado no falatório. A angústia deixa-nos sem alojamento, sem apoios nem defesas, isto $\boldsymbol{e}$, provoca uma suspensão, uma pendência, deixa-nos prontos para sermos tomados de assalto pelo nada a qualquer instante. Com isso, a experiência da angústia faz do homem o seu Dasein, dispõe-no em seu ser-no-mundo.

A angústia é a experiência pela qual temos o acesso privilegiado ao nada. O nada não é de maneira alguma uma representação conceitual, não se apresenta no âmbito do entendimento. O nada, do ponto de vista ontológico, não se encerra nessas possibilidades. Segundo Heidegger: "o nada se revela na angústia - mas não enquanto ente. Tampouco nos é dado como objeto [...] na angústia deparamos com o nada juntamente com o ente em sua totalidade." ${ }^{24}$ O nada é um momento de essencialização do ser, que se dá num plano anterior àquele dos esforços de enunciação determinante na forma do $\boldsymbol{e}$. No modo de ser impróprio, que se caracteriza pela fuga da responsabilidade na convivência cotidiana, na impessoalidade, no saber das ocupações e afazeres comuns não há lugar para o nada. $\mathrm{O}$ homem enquanto ente finito existe sempre pendente no nada, ainda que raramente se dê conta disso, nos instantes em que é possuído pela angústia fundamental. A angústia está aí, mas ela é abafada pela proteção que o si-mesmo impróprio despoja na ambiguidade e no falatório. Ela está

\footnotetext{
${ }^{22}$ HEIDEGGER, M. "Was ist Metaphysik?" In: Wegmarken, GA 9. Op. cit., p. 111.

${ }^{23}$ Ibid., p. 111.

${ }^{24}$ Ibid., p. 113.
} 
continuamente à espreita e, contudo, apenas raramente salta sobre nós para arrastar-nos para a flutuação em suspenso, para a nossa compreensão da existência à luz do ser-para-a-morte.

A angústia originária aprofunda ontologicamente a questão da escolha entre o próprio, quer dizer, a escolha por escutar a voz responsabilizadora da consciência do ser e estar em débito, que veremos mais adiante, ser si-mesmo próprio; e o impróprio, que é a escolha por deixar-se guiar pelo poder-ser impróprio, é a recusa de assumir a finitude. Não é difícil perceber que, o homem, imerso na impropriedade da publicidade de início e na maioria das vezes a partir do que se ocupa, no mundo do cotidiano, conduzido pelo falatório e ao eu-também, não responde ao apelo da resposta ao ser. Apenas a angústia, na medida em que desaba e silencia a proteção da impropriedade do falatório sobre o ente, é capaz de impelir o Dasein impróprio a se abrir, ou melhor, a assumir o seu poder-ser próprio.

A angústia fundamental, enquanto possibilitadora da propriedade do Dasein, propicia uma experiência do ser como o outro de todo ente. Não podendo jamais ser encontrado como ente, o ser vem à luz como o inteiramente outro em relação ao ente, como o não-ente, como nada. É o que se lê em Was ist Metaphysik?: "o nadificar do nada não é um episódio casual, mas, como remissão (que rejeita) ao ente em sua totalidade em fuga, ele revela este ente em sua plena, até então oculta, estranheza como o absolutamente outro - em face do nada. ${ }^{25}$ Dessa maneira, temos o nada como o outro do ente, noutros termos, como o véu do ser. Ou seja, o velamento do ser é a nadificação do ser. Esta perspectiva de Heidegger situa-se na sua crítica ao projeto metafísico da subjetividade e de seu respectivo assenhoramento conceitual do ser. Estar suspenso dentro do nada implica o fato de que não há um fundamento para a existência, senão o próprio fundamento sem fundo da finitude do ser-no-mundo. É o fundo abismal (Abgrund) da existência que aparece descoberto pela angústia, o nada do Dasein.

A angústia rompe com a familiaridade cotidiana do Dasein, fazendo desabar a tranquilidade que o si-mesmo impróprio despojava no impessoal. Como diz Ricoeur, "o ser do si supõe a totalidade de um mundo que é o horizonte de seu pensamento, de seu fazer, de seu sentir - em suma, de sua preocupação." ${ }^{26} \mathrm{E}$ este quadro de referência é a totalidade de seu mundo que emudece, revelando-se no nada de fundamento. O Dasein sente-se fora de casa, pelo menos temporariamente, os entes intramundanos se afastam, afundam em um nada

${ }^{25}$ Ibid., p. 114.

${ }^{26}$ RICOEUR, P. O si-mesmo como um outro. Trad. de Lucy M. Cesar. Campinas: Papirus, 1991.p. 363. 
e em nenhum lugar, se está des-familiarizado com aquilo que antes era pura familiaridade. A angústia retira do Dasein a possibilidade de compreender a si mesmo a partir do mundo e da interpretação pública. Na angústia, a condição intransponível de finitude da existência humana é experimentada então como uma liberdade para encontrar-se com sua própria morte, um estar preparado para e um contínuo estar relacionado com sua própria morte.

Assim, a angústia coloca o Dasein numa perplexidade porque aponta para o nada de seu fundamento como ser-no-mundo. O Dasein existe como ser possível, isto é, referido a possibilidades existenciais. É nesta situação que a angústia rompe com a tranquilidade do sentir-se em casa do que é público, pois, aí, o Dasein aparece no modo existencial do não se sentir em casa, “[...] isto é, da estranheza inerente ao Dasein enquanto ser-no-mundo lançado para si mesmo em seu ser." ${ }^{\prime 27}$ Por isso, Heidegger afirma que o não sentir-se em casa deve ser compreendido como fenômeno mais originário, porque, justamente, $o$ Dasein é ec-sistência. Isso significa que o Dasein está desde sempre fora, o seu si-mesmo é sempre algo além de si, é seu ser-no-mundo. A estranheza presente na angústia é o que desvela para o Dasein a sua constituição de ser-no-mundo. O Dasein próprio, aberto para sua morte, compreende sua temporalidade de uma maneira finita. Assim, uma outra possibilidade de dizer a angústia que nos deixa diante do nada, é dizer que ela nos deixa diante da finitude irremissível de nosso ser-no-mundo. É só através da angústia que descobrimos o mundo enquanto mundo. O mundo enquanto tal é uma transcendência finita; transcender é ser-no-mundo. Nesse sentido, é isto o que a angústia faz: singulariza o Dasein em seu próprio ser-no-mundo; fugir da angústia é fugir de ser-no-mundo: "no Dasein, a angústia revela o ser para o poder-ser mais próprio, ou seja, o ser-livre para a liberdade de escolher e acolher a si mesmo." ${ }^{28}$ Por meio da experiência da angústia, pode-se dizer que o Dasein faz de uma só vez uma re-significação de toda sua existência e toma consciência do caráter essencialmente finito de sua existência. O Dasein se angustia diante da facticidade da responsabilidade pelo seu próprio ser para possibilidades; ou seja, aquilo mesmo pelo que a angústia se angustia, é o seu próprio poder-ser.

Nesse sentido, a ontologia fundamental pode, possivelmente, ser lida como uma ética. Desde Sein und Zeit, quando Heidegger pergunta pelo sentido do ser e se esforça em substituir a metafísica tradicional pelo que chama de ontologia fundamental, ele está também a colocar em xeque os sistemas morais das éticas tradicionais que têm suas raízes metafísicas. Isto, Heidegger faz na medida em que aponta que há um ethos, uma maneira de habitar, de ser-no-mundo

${ }^{27}$ HEIDEGGER, M. Sein und Zeit. Op. cit., p. 189.

${ }^{28}$ Ibid., p. 188. 
- chamada por ele de Dasein - que não pode ser determinado por nenhum princípio supremo. A ética que vislumbramos em Sein und Zeit diz que o Dasein tem-que realizar o seu ser, mas só pode assumir o seu poder-ser próprio quando se decide a ouvir a voz da consciência do ser-em-débito, ouvida no silêncio disposto para a angústia, que nada mais é do que uma manifestação da abertura ao mundo do Dasein: o estar-no-mundo próprio é fruto da responsabilidade para com o Dasein como tal e para com os outros. É na escuta apropriada, que pressupõe o silêncio atencioso, que o Dasein se manifesta aberto ao seu ser mais próprio, bem como se abre de maneira mais própria ao outro, compreendendo-o não como um ente meramente presente, mas enquanto o outro Dasein que ele é. Assim, o horizonte teórico de Sein und Zeit nos permite pensar uma ética de ser-no-mundo, do morar no mundo-projeto, do morar na transcendência finita, do abrir-se para o encontro, pois o ser-no-mundo "é sempre, na origem, um movimento de abertura de possibilidades para o outro, um cuidar." 29

\section{O ser-para-a-morte e o caráter de apelo da consciência}

A angústia desponta quando o Dasein depara-se com a sua possibilidade mais própria: a morte. O Dasein é, no seu modo mais primordial, ser-para-a-morte, expressão que indica o seu caráter de finitude: "cada Dasein deve, ele mesmo e a cada vez, assumir a sua própria morte. Na medida em que 'é', a morte é, essencialmente e cada vez, minha." ${ }^{30}$ A morte não é mais uma possibilidade que surge a partir do modo de ser-no-mundo, mas, todavia, a nossa possibilidade mais própria e extrema, quer dizer, ninguém pode experimentar a morte do outro. Ninguém pode morrer por outro. A morte a que, na cotidianidade, o Dasein refere-se, não é ainda a sua morte, pois é tida sob o domínio da interpretação pública. Em Sein und Zeit, Heidegger escreve o modo como o impessoal define a morte da seguinte maneira:

Diz-se que a morte certamente vem, mas por ora ainda não. Com esse "mas", o impessoal retira a certeza da morte. O "por ora ainda não" não é mera proposição negativa e sim uma auto-interpretação do impessoal, em que ele testemunha aquilo que, numa primeira aproximação, ainda permanece acessível e passível de ocupação para o Dasein [...] O impessoal encobre o que há de característico na certeza da morte, ou seja, que é possível a todo instante. ${ }^{31}$

Como pudemos observar, o próprio do cotidiano é o impessoal e, enquanto

\footnotetext{
${ }^{29}$ LOPARIC, Z. Ética e Finitude. Op. cit. p. 61.

${ }^{30}$ HEIDEGGER, M. Sein und Zeit. Op. cit., p. 240.

${ }^{31}$ Ibid., p. 258.
} 
tal, revela ao Dasein de que modo ele deve se compreender; no caso da morte, também dita de que modo esta deve ser compreendida: o teor público da convivência cotidiana conhece a morte como uma ocorrência que sempre vem ao encontro, ou seja, como casos de morte. O impessoal, assim, já sempre se encarregou de que modo a morte deve ser concebida, ou seja, a morte é um acontecimento que um dia ocorrerá, mas, por certo, ainda está muito distante, morreremos no dia em que chegar a nossa hora, mas até lá, não temos com o que nos preocupar. A certeza da morte, por sua vez, se mostra como uma certeza empírica, ou seja, o Dasein tem a certeza da morte, ela é comprovada, as pessoas morrem, a morte torna-se evento público, mas é um acontecimento que, anterior a tudo, é também incerto e indeterminado quanto ao seu dia. "Nesse 'também um dia [se morre] mas por ora ainda não', a cotidianidade assevera uma espécie de certeza da morte. Ninguém duvida de que se morre." ${ }^{32}$ E completa Heidegger, "a cotidianidade pára no momento em que admite ambiguamente a 'certeza' da morte a fim de enfraquecê-la e aliviar o estar-lançado na morte, encobrindo ainda mais o morrer." 33

O ser-para-a-morte é a escolha antecipada da possibilidade mais própria do Dasein. A compreensão, enquanto antecipação, é compreensão de si no âmbito de um projeto lançado no mundo: "a liberação antecipadora para a própria morte liberta do perder-se nas possibilidades ocasionais, permitindo assim compreender e escolher em sentido próprio as possibilidades fácticas que se antepõem às insuperáveis. ${ }^{" 34}$ Por outro lado, Heidegger assegura que ser para uma possibilidade não significa empenhar-se por algo possível, no sentido de ocupar-se de sua realização. Isto quer dizer que o ser-para-a-morte, enquanto ser aberto para uma possibilidade, para algo possível, não possui o mesmo sentido que tem o "caráter de empenho que se ocupa de sua realização [...] a morte enquanto algo possível não é um manual e nem algo simplesmente dado possível, e sim uma possibilidade de ser do Dasein." ${ }^{35}$

Em Heidegger, a noção de finitude (Endlichkeit) é pensada no âmbito da ontologia, e, portanto, mantém-se distante do apelo ao infinito ou a um fundamento entitativo. Ser finito é a constituição fundamental da existência humana: "o homem é um ente finito porque o seu ser é cindido em possibilidades 'mundanas', as que constituem o seu ser-no-mundo, e numa possibilidade 'extramundana', a de não-poder-mais-ser-no-mundo, a de ser-para-a-morte."’36

\footnotetext{
${ }^{32}$ Ibid., p. 255.

${ }^{33}$ Ibid., p. 255-256.

${ }^{34}$ Ibid., p. 264.

${ }^{35}$ Ibid., p. 261.

${ }^{36}$ LOPARIC, Z. Heidegger réu: um ensaio sobre a periculosidade da filosofia. Campinas: Papirus, 1990. p. 184.
} 
Não há como superar essa cisão ontológica, pois se trata da sina que o homem está fadado a carregar, pois a morte, enquanto possibilidade do poder-ser do Dasein, constitui a sua possibilidade mais própria. O estar aberto a responder ao sentido do ser diz respeito, então, a uma não-identidade fundadora, denominada por Heidegger de diferença ontológica. Ter que responder ao sentido do ser si-mesmo significa, na origem, ter que se haver com a cisão.

Cada Dasein deve, ele mesmo e a cada vez mais, assumir a sua própria morte. Então, que devemos fazer? Escolher por escutar a voz da consciência do ser-em-débito, isto é, escolher ser si-mesmo próprio; ou escolher por deixar-se guiar pelo seu poder-ser impróprio, pela publicidade, recusando-se a assumir a sua finitude. É nesse sentido que, para Heidegger, querer-ter-consciência significa estar aberto à compreensão de seu ser e estar em débito mais próprio, isto é, ter cuidado com o seu ser, antecipando-se à morte. Sendo assim, a morte não é meramente uma propriedade que nos pertence, mas é a possibilidade da impossibilidade mais extrema de cada Dasein. Trata-se da antecipação resoluta e angustiada de poder-não-mais-ser.

O ser para essa possibilidade coloca o Dasein diante de seu poder-ser mais próprio; é se antecipando que o Dasein compreende que o seu poder-ser só pode ser assumido por ele mesmo. Mas essa possibilidade é, na verdade, uma impossibilidade. Estamos diante de um paradoxo: a nossa possibilidade mais própria e irremissível é, também, a que impossibilita continuarmos a existir no mundo. Todavia, este não é o aspecto mais importante para Heidegger; ele não tem interesse em afirmar uma mera tautologia: que a morte inviabiliza a continuidade de nossa existência, mas o que podemos retirar de nossa condição de ser-para-a-morte é compreender o que acontece conosco quando tomamos consciência dessa impossibilidade. Ao tomarmos consciência dessa possibilidade mais extrema, o nosso morrer, teríamos a experiência de transformar todas as possibilidades de nossa existência, como algo decorrente do antecipar a morte. Dessa maneira, a morte não se coloca ao Dasein de forma indiferente, antes, é a possibilidade do seu morrer que possibilita que o Dasein reivindique-se para si mesmo enquanto singularidade. É na antecipação da possibilidade intransponível do ser-para-a-morte que o Dasein pode, finalmente, responsabilizar-se propriamente por si. A antecipação faz com que o Dasein, livre para a sua morte, se liberte das possibilidades ocasionais que the são oferecidas cotidianamente pelo impessoal.

Nesse sentido, é o ser-para-a-morte que determina a totalidade do ser do Dasein, ou seja, a totalidade do cuidado; é na relação própria com a morte que o cuidado revela o que há de mais próprio ou autêntico. Assim, a voz da consciência dá a compreender ao Dasein que ele é e está em débito, ou seja, que, enquanto lançado no mundo, estranho a si mesmo envolvido na curiosidade, 
na tagarelice, na ambiguidade de seu ser-impessoal, ele tem-que assumir o seu ser-para-a-morte, antecipar-se à morte, responsabilizar-se por sua existência e pela existência dos outros, na medida em que, livre para assumir o seu poder-ser mais próprio, ele ajuda o outro a ficar transparente para si mesmo. O querer-ter-consciência dá-se como uma modificação fundamental no modo de existir. É só assim, ouvindo a voz da consciência que responsabiliza, resoluto e decidido por ser si-mesmo, que o Dasein é capaz de relações autênticas com outrem, capaz de solicitude que antecipa e liberta o outro dele próprio. ${ }^{37}$

Mas, de onde vem a indicação existencial da noção de débito, de responsabilidade atestada na voz da consciência? Do fato de o Dasein estar assentado numa falta, "por isso, determinamos de maneira existencial e formal a ideia de 'débito' do seguinte modo: ser-fundamento de um ser determinado por um não, isto é, ser-fundamento de um nada." ${ }^{38}$ Heidegger ressalta que a noção do débito não tem o mesmo sentido de uma dívida, assumida no mundo das ocupações. Para compreender este débito é necessário afastá-lo de todas as suas interpretações correntes, presentes no domínio moral, prático e religioso, no sentido de dívida; se bem que estas manifestações (ônticas) são derivadas do débito, enquanto condição de possibilidade (ontológico). Não se pode dizer que o Dasein é e está em débito porque não cumpriu com uma paga qualquer e deve-se restituir a outrem algo a que ele tem direito, o débito "não está necessariamente remetido ao 'ter dívidas' e à violação do direito, só pode ter êxito caso se coloque em questão o princípio do ser e estar em débito do Dasein, ou seja, caso se conceba a idéia de 'débito' a partir do modo de ser do Dasein." 39

Com isso, o ser-em-débito não se refere de maneira nenhuma a alguma espécie de exigência moral, não se está em débito por ter violado algum acordo público moral. Nestas interpretações, o débito é algo de ôntico, que, portanto, foi contraído, do mesmo modo que poderia não ter sido contraído. Antes e mais fundamentalmente, a noção de débito faz parte da constituição ontológica desse ente: "o ser e estar em débito não resulta primordialmente de uma causa; ao contrário, a causa só é possível 'fundamentada' num ser e estar em débito originário." ${ }^{\prime 40}$ Esse ser já em débito aponta para o débito como algo proveniente da condição ontológica do ser mesmo do Dasein. Anterior a toda e qualquer dívida em relação a outrem, o Dasein encontra-se em débito com seu próprio

${ }^{37}$ Cf. HAAR, M. Heidegger e a essência do homem. Trad. de Ana Alves. Lisboa: Instituto Piaget, 1997. p. 58.

${ }^{38}$ HEIDEGGER, M. Sein und Zeit. Op. cit., p. 283.

${ }^{39}$ Ibid., p. 283.

${ }^{40}$ Ibid., p. 284. 
ser, um débito que aponta o ter-que-assumir o ser que a cada vez é meu na constituição ontológica do não-mais-ser-no-mundo.

$\mathrm{Na}$ ontologia fundamental, a consciência (Gewissen) é uma constituição ontológica do Dasein, um fenômeno originário que "antecipa toda descrição psicológica de suas vivências e sua classificação, estando também fora de uma 'explicação' biológica [...] Também não é menor a distância que a separa de uma interpretação teológica." ${ }^{41}$ Do mesmo modo, o ser-em-débito (Schuldgsein) está livre de conotação moral ou religiosa que oferece instruções sobre o certo e o errado. Ricouer dá ênfase ao sentido primordial de Gewissen como atestação (Bezeugung) antes de qualquer referência que possa fazer à capacidade de distinguir o bem e o mal e de responder a essa capacidade pela distinção boa e $m a ́$ consciência. ${ }^{42}$ Tal fenômeno da consciência, ressalta Ricoeur, teria, em Heidegger, o significado de um arrancamento do si ao anonimato do impessoal, a ideia de um apelo que o Dasein dirige a ele mesmo do fundo dele mesmo, mas de mais alto dele mesmo. O ponto que Ricoeur destaca a respeito da Gewissen é este: da íntima atestação de existir segundo o modo do si, o ser não tem o domínio; ele vem a ele, advém-lhe, à maneira de um dom, de uma graça, de que o si nunca dispõe. Ao dizer com Heidegger que é a consciência que atesta um poder-ser próprio, que na consciência o Dasein chama-se ele mesmo, é já decidir uma indeterminação constitutiva do fenômeno da voz da consciência: a estranheza da voz não é menor do que a da carne e a de outrem. ${ }^{43}$ Tudo se passa como se, para sublinhar Sein em Dasein, nós evitássemos reconhecer alguma força originariamente ética ao apelo. Certamente, não importa de onde vem (origem) o apelo nem o que ele clama (conteúdo), nada se anuncia que não esteja já nomeado sob o título de poder-ser. ${ }^{44}$ É o próprio Dasein que, aberto a uma compreensão de si, pode conceder a si mesmo a possibilidade de se deixar convocar pelo seu querer-ter-consciência de ser-em-débito.

Segundo Hodge, a moralidade, entendida como uma série de distinções entre o bem e o mal, é derivada de uma estrutura mais básica, sem a qual não seria possível a possibilidade do julgamento. Assim, o ser-em-débito não está relacionado a um não cumprimento de alguma lei, norma ou obrigação; antes, resulta de uma incompletude que Heidegger chamou de Schuldgsein. Trata-se de uma nulidade, de uma falta de fundamento: “é uma característica ontológica do Dasein, o fato de ter uma relação consigo mesmo e ser suficientemente

\footnotetext{
${ }^{41}$ Ibid., p. 269.

${ }^{42}$ Cf. RICOUER, P. O si-mesmo como um outro. Op. cit., p. 361.

${ }^{43}$ Cf. Da metafisica à moral. Trad. de Sílvia Menezes. Lisboa: Instituto Piaget, 1997. p. 35-36.

${ }^{44}$ Cf. O si-mesmo como um outro. Op. cit., p. 405.
} 
indeterminado para ser responsabilizado pelos seus atos e omissões." ${ }^{35} \mathrm{~A}$ escuta do clamor retira o Dasein de seu ser no mundo para remetê-lo ao poder-ser. De início e na maioria das vezes, o Dasein já perdeu essa dimensão de seu ser, pois está submerso nas possibilidades ônticas que ele assumiu durante sua existência, acreditando que ele mesmo é constituído dessas possibilidades e que, então, não poderia não sê-las. A voz do clamor é aquilo que vai sempre devolver-lhe a responsabilidade por aquilo que ele é. Compreender o clamor é escolher ter-consciência. É o próprio Dasein que é convocado a ser si-mesmo em sentido próprio. No entanto, essa convocação responsabilizadora, atestada na consciência, nada diz para o convocado, este chamado não se pronuncia em palavras, antes se dá silenciosamente. A voz que discursa na consciência do convocado, dispensa qualquer verbalização, o clamor não relata nenhum dado, discurso ou conteúdo, a fala da consciência sempre e apenas se dá em silêncio. Essa voz responsabilizadora da consciência provém do e fala sobre o Dasein:

A consciência revela-se como apelo de cura [apelo, chamado do cuidado]: quem apela é o Dasein que, no estar-lançado (já-ser-em...), angustia-se com o seu poder-ser. O interpelado é justamente esse Dasein conclamado para assumir o seu poder-ser mais próprio (anteceder-se...). Apela-se ao Dasein, interpelando-o para sair da decadência no impessoal (já-ser-junto-ao-mundo-das-ocupações) ${ }^{46}$

Querer ouvir a voz significa abrir-se, dispor-se a cuidar do ser. Apenas recebe a voz quem escolhe, quem decide por esse poder-ser a partir do seu ser si-mesmo próprio. Uma consciência não me diz que opções específicas escolher ou evitar, mas convoca-me a escolher, a agir, e a assumir a responsabilidade por essa escolha e essa ação. Antes de poder escolher, tenho de optar por escolher, e é a essa escolha que a consciência me chama. Por outro lado, Heidegger assinala que, na cotidianidade, o Dasein dá ouvidos ao que é dito pela publicidade, de tal modo que o Dasein já se entregou à compreensão forjada no âmbito do impessoal, quer dizer, já deu ouvidos àquilo que é dito como o que deve ser feito. Essa voz da publicidade, por sua vez, é apoiada numa ambiguidade múltipla, é uma falação curiosa que, de início e no mais das vezes, impede que o Dasein dê ouvidos a si mesmo; o Dasein aceita essa fala porque tem a tendência a se perder no seio do cotidiano. É por isso que Heidegger aponta que o Dasein precisa ouvir a voz responsabilizadora longe de todo o ruído do falatório, "[...] o apelo deve apelar sem ruído, sem ambiguidade, sem apoiar-se na curiosidade", ${ }^{47}$ precisa propiciar a si mesmo a possibilidade de dar ouvidos

\footnotetext{
${ }^{45}$ HODGE, J. Heidegger e a ética. Op. cit., p. 298-299.

${ }^{46}$ HEIDEGGER, M. Sein und Zeit. Op. cit., p. 277-278.

${ }^{47}$ Ibid., p. 271.
} 
a si mesmo: precisa se responsabilizar por si mesmo.

A voz da consciência do ser-em-débito dá a compreender ao Dasein que ele tem que assumir o seu ser-para-a-morte, ou seja, responsabilizar-se por sua própria existência e pela existência dos outros, na medida em que, livre para assumir o seu poder-ser mais próprio, o homem finitizado, cuidará, em primeiro lugar, não de substituir os outros em sua decisão resoluta, mas de deixar os outros também livres para a sua possibilidade mais própria: a de não-poder-mais-ser-aí-no-mundo. É somente agindo assim, atendendo ao apelo da consciência responsabilizadora, que o Dasein é capaz de relações autênticas com outrem. A voz da consciência, afinada com a angústia, fala de um débito, de uma responsabilidade a ser assumida, por outro lado, essa voz fala em silêncio, justamente porque ela não se refere a algum conteúdo a ser seguido, mas convoca o Dasein a ser si-mesmo sustentado no nada da sua própria condição: na possibilidade de não-poder-mais-ser-aí-no-mundo. É neste ponto que, numa passagem do $\S 34$ de Sein und Zeit, encontramos o seguinte: "o estar em silêncio articula em forma tão originária a compreensibilidade do Dasein que dele provém a autêntica capacidade de escutar e o transparente ser uns com os outros. ${ }^{" 48}$ Em sua serenidade, o silêncio revela a postura do Dasein para com o apelo da voz do ser. Compreendendo esse chamado, o Dasein restitui para si a possibilidade de poder escolher, o que significa dizer que o Dasein escolhe a si mesmo; o Dasein decide por responder por si mesmo propriamente:

Compreendendo o apelo, o Dasein deixa que o si-mesmo mais próprio aja dentro dele a partir da possibilidade de ser escolhido. Apenas assim ele pode ser responsável. Facticamente, porém, toda ação é necessariamente "desprovida de consciência" não só porque ela de fato evita a culpabilização moral mas porque, fundada no nada de seu projeto nulo, sempre já está em débito com os outros. ${ }^{49}$

O ser-em-débido, surge, portanto, como um chamado, apelo ou ainda uma voz que oferece ao Dasein a possibilidade de se compreender em seu poder-ser mais próprio e, é nesse sentido, que podemos apontar o conceito existencial-ontológico de ser-em-débito como um conceito pré-ético, pertinente às condições a priori de possibilidade da moralidade do Dasein humano. ${ }^{50}$ Nesse viés, a voz da consciência dá a compreender ao Dasein que ele se abre como ser e estar em débito, ou seja, o Dasein é lançado no mundo e, enquanto se relaciona com o mundo segundo um modo de ser predominante

\footnotetext{
${ }^{48}$ Ibid., p. 165.

${ }^{49}$ Ibid., p. 288.

${ }^{50}$ Cf. DUARTE, A. Por uma ética da precariedade: sobre o traço ético de Ser e Tempo. Op., cit., p. 86.
} 
- na ambiguidade de seu ser-impessoal -, ele tem que escolher entre as suas possibilidades uma possibilidade intransponível, a mais própria: a de ser-para-a-morte. Isto siginifica que o caráter propriamente ético de Sein und Zeit encontra-se atrelado às condições ontológicas da angústia, da escolha antecipada da morte e do chamado silencioso da voz da consciência. Apenas a modificação do si-impessoal que desencobre o si-mesmo-próprio pode permitir ao Dasein a possibilidade do encontro de si e dos outros em sua alteridade própria, sem o que nenhuma relação ética se faria possível. ${ }^{51}$

Visto isso, observamos que a partir da antecipação resoluta, angustiada e silenciosa do poder-não-mais-ser, a responsabilidade decorre em dois planos: o ontológico e o ôntico. No nível ontológico, a responsabilidade de responder pela diferença ontológica como tal implica a tarefa do Dasein ser si-mesmo à luz da possibilidade irremissível de ser-para-a-morte. A diferença ontológica é a quebra com a identidade metafísica entre ser e ente. É nesse ponto que passamos ao modo pelo qual se dá a responsabilidade no plano ôntico. Nesse sentido, Loparic afirma que a "a responsabilidade para com o sentido do ser estende-se à responsabilidade para com a presença concreta dos outros seres humanos e das coisas." ${ }^{\prime 2} \mathrm{E}$, mais adiante, o autor conclui que cuidar dos outros, em particular, é deixar-ser os outros nas suas responsabilidades ônticas. Além de termos a responsabilidade para com a transcendência dos outros, temos que suportar o peso da sua concretude mundana, preocupando-nos com os membros de comunidades em que vivemos (famílias, comunidades de trabalho etc.). ${ }^{53}$

É somente assim, ouvindo a voz da consciência que responsabiliza, que o Dasein é capaz de relações autênticas com outrem, capaz de solicitude que antecipa e liberta o outro dele próprio. Portanto, ser solícito significa cuidar do outro como acontecência finita, não como membro de um coletivo que obedece ao enquadramento normativo da razão. O sentido da responsabilidade do Dasein é de se manter aberto à compreensão do sentido do ser e à estrutura de seu ser-no-mundo e, também, de cuidar dos outros entes encontrados no mundo-projeto como acontecência finita do seu existir enquanto livres de todas as normas da razão suficiente. O caráter ético da ontologia fundamental transparece ao se esclarecer de que modo a relação do Dasein para consigo deve abrir o outro como outro. Assim, a possibilidade de uma ética da finitude estaria direcionada ao caráter da autenticidade do si mesmo. O Dasein é o "lugar em que ocorre um processo de autoconstituição, através de um processo de individuação auto-afirmante, e que culmina na afirmação do Selbstsein, ser-

\footnotetext{
${ }^{51}$ Cf. Ibid., p. 87.

${ }^{52}$ LOPARIC, Z. Sobre a responsabilidade. Porto Alegre: EDIPUCRS, 2003. p. 39.

${ }^{53}$ Cf. Ibid., p. 39-40.
} 
-se si próprio." ${ }^{54}$

Finalmente, apontamos que a desconstrução heideggeriana da metafísica implicou, também, na desconstrução da ética infinitista. Nessa perspectiva, a ética da finitude torna-se possível somente a partir da ontologia fundamental que, por sua vez, inaugurou o pensamento de retorno ao sentido do ser com base no horizonte do tempo finito do existir humano; pensou o Dasein enquanto fundamento negativado, portanto, distante do princípio do fundamento. $\mathrm{Ou}$ seja, buscamos demonstrar que a ética da finitude, não podendo mais tomar como apoio e fundamento princípio algum, mesmo porque desconstruiu todos, remeteu a cada um o fardo a ser suportado da sua própria existência, como também, a responsabilidade a ser assumida por cada um em seu poder-ser si mesmo. Assim, o Dasein não é ético porque corresponde ao tribunal da razão normativa, mas é ético porque tem que se haver consigo mesmo e com os outros no mundo que é sempre compartilhado, sem que para tanto possa contar com garantias de salvação ou recompensa; o nada que perpassa a existência do Dasein é parte fundamental constitutiva de seu modo de ser enquanto ser-em-débito. É no querer-ter-consciência desse ser e estar em débito que o Dasein se permite a si mesmo, numa decisão antecipadora, se assumir enquanto ser finito que se é no mundo. A consciência, por conseguinte, se mostrou como um testemunho fundamental do ser do Dasein onde ele é chamado a ser si mesmo próprio, ou seja, onde ele é chamado a assumir a responsabilidade de existir como fundamento nulo, o de ser-para-a-morte, de poder-não-mais-estar-no-mundo. Portanto, o ser-no-mundo próprio se dá por meio da responsabilidade para com o Dasein como tal e para com o mundo compartilhado, transmitida (überantwortet) ao homem pela não-identidade consigo mesmo, cisão reveladora da diferença ontológica entre o ainda-sim e não-mais.

\section{Referências}

DUARTE, A. Por uma ética da precariedade: sobre o traço ético de Ser e Tempo. In: Revista Natureza Humana, São Paulo, ano 1, v. 2., n. 1, 2000.

FERRY, L; RENAULT, A. La Question de l'éthique après Heidegger. In: Système et Critique. Essais sur la critique de la raison dans la philosophie contemporaine. Bruxelles: Ousia, 1992.

HAAR, M. Heidegger e a essência do homem. Trad. de Ana Alves. Lisboa: Instituto Piaget, 1997.

HEIDEGGER, M. "Brief über den »Humanismus«". In: Wegmarken, GA 9. Frankfurt am Main: Vittorio Klostermann, 1976.

. Sein und Zeit. Tübingen: Max Niemeyer Verlag, 1967.

${ }^{54}$ HODGE, J. Heidegger e a ética. Op. cit., p. 266. 
. Was ist Metaphysik? In: Wegmarken, GA 9. Frankfurt am Main: Vittorio Klostermann, 1976.

HODGE, J. Heidegger e a ética. Trad. de Gonçalo C. Feio. Lisboa: Instituto Piaget, 1998.

KIERKEGAARD, S. A. O desespero humano: doença até a morte. Trad. de Adolfo C. Monteiro. São Paulo: Abril Cultural, 1979.

LOPARIC, Z. Ética e finitude. 2. ed. São Paulo: Escuta, 2004.

. Heidegger réu: um ensaio sobre a periculosidade da filosofia. Campinas:

Papirus, 1990.

Sobre a responsabilidade. Porto Alegre: EDIPUCRS, 2003.

NUNES, B. Crivo de papel. 2. ed. São Paulo: Ática, 1998.

- Passagem para o poético: filosofia e poesia em Heidegger. São Paulo: Editora Ática, 1992.

RICOEUR, P. Da metafísica à moral. Trad. de Sílvia Menezes. Lisboa: Instituto Piaget, 1997. 1991.

. O si-mesmo como um outro. Trad. de Lucy M. Cesar. Campinas: Papirus,

\title{
RESUMO
}

Neste trabalho, analisaremos a possibilidade de uma leitura ética na ontologia fundamental heideggeriana. Mostraremos de que forma o horizonte teórico de Sein und Zeit permite pensar uma ética originária, uma ética de ser-no-mundo cuja base não pode ser outra senão a finitude humana.

Palavras-chave: Ontologia fundamental; ser-no-mundo; finitude; angústia

\begin{abstract}
In this paper we shall analyze the possibility of an ethical reading in Heidegger's fundamental ontology. We shall show in what form the theoretical horizon of Sein und Zeit permits us to think an original Ethics, an Ethics of being-in-the-world the base of which can be no other than human finitude.
\end{abstract}

Key-words: Fundamental ontology; being-in-the-world; finitude; anguish 